\title{
Prediction of the Crushing Strength of Sda-Clay Fired Bricks Using Simplex Theory
}

\author{
${ }^{1}$ D.O. Onwuka, ${ }^{2}$ C.Chijioke, ${ }^{3}$ S.U. Onwuka \\ ${ }^{1,3}$ Civil Engineering Federal University of Technology, Owerri Nigeria \\ ${ }^{2}$ Civil Engineering Department Federal Polytechnic Nekede Owerri Nigeria
}

\begin{abstract}
Waste materials have been found useful in the production of new building materials. The addition of sawdust ash (SDA) an industrial waste generated by the timber industry, to burnt bricks raw mixes leads to the production of bricks of lighter weight and higher refractive properties. It also solves the problem of waste disposal and management.

However, the development of a model for the prediction of the crushing strength of the new product (ie SDA-clay burnt bricks) is a critical factor in the production and use of SDA-clay burnt bricks as cheap and affordable building material. This article presents a response function based on simplex theory, for the prediction of the crushing strength of SDA-clay burnt bricks when given a specific mix proportion of its components, and vice versa. The results obtained from the simplex response function developed, are in total agreement with the corresponding crushing strength test results. The use and application of the response function will eliminate the tedious, expensive and time consuming trial- mix design methods.
\end{abstract}

Keywords: Clay, Sawdust Ash (SDA), Burnt bricks, Simplex theory, Response function and Crushing strengths.

\section{Intoduction}

Sawdust is an industrial waste generated by the timber. It causes nuisance both to the health and environment when not properly disposed (Elinwa, 2006). The general trend for the industrial waste or byproduct is to develop alternative ways for their exploitation in order to eliminate cost of disposal, and avoid soil and water contamination (Katsioti et al, 2005).

Various research works have been carried out on the use of the ash from sawdust in the production of clay bricks. Significant among them is the research by Elinwa (2006) on the effect of saw dust on clay bricks. He concluded that though the crushing strength of clay bricks decreases as the percentage by weight of sawdust ash increases, bricks of reasonable strength can be produced. In his own work, Malu et al (2007) established that a mixture of kaolin and sawdust in the ratio of 1:1 by volume was suitable for the production of good quality insulating bricks. Okumade (2008) was able to produce bricks of compressive strength of up to $18.48 \mathrm{MN} / \mathrm{m}^{2}$ when sawdust and wood ash were mixed with clay.

Hence, there is need to determine the optimum amount of sawdust ash required to produce clay bricks of optimum strength. This paper presents a response function based on simplex theory for the prediction of the crushing strength clay bricks incorporating a specified amount of sawdust ash. The response function can also be used to predict various mix proportions that can give-SDA clay bricks of a particular crushing strength.

\subsection{Sawdust}

\section{Materials}

Sawdust, a waste-product from the timber industry, was collected from timber sawmills in Owerri. The predominant species of wood milled by the sawmills, are Iroko, Mahogamy, Abura, Afara and Obeche. The sawdust used in the production of the SDA clay fired bricks tested, was obtained by open burning in an open drum. It was then, ground to very fine powder using mortar and pestle, and sieved with a 212 um British test sieve. The characteristics of the SDA are given in Tables 1 and 2.

\subsection{CLAY}

The clay is obtained from Isu Ihime locality, which has a long standing history for brick making, and so it is called Isu clay. It was crushed and soaked in water for 2 days in order to remove unwanted organic materials. This was followed by drying and subsequent grinding to finer particles. The characteristics of the clay are given in Tables 1 and 2 . 
Table 1 :Physical properties of Clay and SDA

\begin{tabular}{|c|c|c|}
\hline \multirow{2}{*}{ Parameter } & \multicolumn{2}{|c|}{ Material } \\
\cline { 2 - 3 } & Clay & SDA \\
\hline Specific Gravity & 2.45 & 2.29 \\
\hline Bulk Density $\left(\mathrm{Kg} / \mathrm{m}^{3}\right)$ & 1610 & 831 \\
\hline Moisture Contents (\%) & 0.63 & 0.37 \\
\hline Loss on Ignition & - & 4.67 \\
\hline
\end{tabular}

Source: Elinwa (2006)

Table 2: Chemical properties of Clay and SDA

\begin{tabular}{|c|c|c|}
\hline \multirow[t]{2}{*}{ Constituents } & \multicolumn{2}{|c|}{ Materials Percentage by weight } \\
\hline & Clay & Sawdust \\
\hline $\mathrm{S}_{\mathrm{i}} \mathrm{O}_{2}$ & 48.5 & 67.2 \\
\hline $\mathrm{Al}_{2} \mathrm{O}_{3}$ & 16.4 & 4.1 \\
\hline $\mathrm{Fe}_{2} \mathrm{O}_{3}$ & 4.1 & 2.3 \\
\hline $\mathrm{CaO}$ & 0.5 & 10.0 \\
\hline $\mathrm{MgO}$ & 0.7 & 5.8 \\
\hline $\mathrm{Na}_{2} \mathrm{O}$ & - & 0.1 \\
\hline $\mathrm{K}_{2} \mathrm{O}$ & 1.4 & 0.1 \\
\hline $\mathrm{SO}_{2}$ & 0.01 & 0.5 \\
\hline $\mathrm{P}_{2} \mathrm{O}_{5}$ & 0.01 & 0.5 \\
\hline $\mathrm{MnO}$ & 0.02 & 0.01 \\
\hline $\mathrm{NiO}$ & 0.1 & 0.05 \\
\hline $\mathrm{Cr}_{2} \mathrm{O}_{3}$ & 0.1 & 0.02 \\
\hline $\mathrm{TiO}_{2}$ & 0.8 & 0.2 \\
\hline MO & 0.1 & 0.04 \\
\hline
\end{tabular}

Source: Elinwa (2006)

\subsection{WATER}

Water is the third material used in the production of the SDA-clay burnt bricks.

\section{Methods}

Two methods, namely, analytical and laboratory methods were adopted in the development of response function for the prediction of the crushing strength of SDA - clay bricks.

\subsection{ANALYTICAL METHOD}

The analytical method is based on the simplex theory for experimental mixtures whose properties depend on the proportions of the constituents. Aggrawal (2002) described experimental mixtures as mixtures produced by mixing of various components required to make a different component. In this work, the raw mixture for SDA - clay bricks, consists of three components, viz, clay, SDA and water.

Let the total number of components in the mixture be ' $\mathrm{q}$ ' and the proportion of the ith component in the mixture be such that:

$$
X_{i} \geq 0(i=1,2,3, \ldots q)
$$

If a unit quantity of the mixture is considered, then for a 3- component mixture,

$\mathrm{X}_{1}+\mathrm{X}_{2}+\mathrm{X}_{3}=1$

Eqn (2) gives a factor space of (q-1) dimension simplex. Writing Eqn (2) in a compact form yields:

$$
\sum_{i=1}^{q} X_{i}=1
$$

The number of coefficients, $\mathrm{K}$, of the second degree polynomial can be obtained from:

$$
K=\frac{(q+m-1) !}{(q-1) ! m !}
$$

where $\mathrm{q}=$ number of components

$$
\mathrm{m}=\text { degree of the polynomial }
$$




\subsubsection{SIMPLEX EQUATION}

The general equation of the simplex function is given by Scheffe's (1958) as:

$$
\begin{aligned}
& \mathrm{Y}=\mathrm{b}_{0}+\sum \mathrm{b}_{\mathrm{i}} \mathrm{X}_{\mathrm{i}}+\sum \mathrm{b}_{\mathrm{ii}} \mathrm{X}_{\mathrm{i}}^{2}+\sum b_{i j} X_{i} X_{j} \\
& +\sum \mathrm{X}_{\mathrm{ijj}} \mathrm{X}_{\mathrm{i}}^{2} X_{j}+\sum \mathrm{b}_{\mathrm{ijj}} \mathrm{X}_{\mathrm{i}} \mathrm{X}_{\mathrm{j}}^{2}+\sum \mathrm{b}_{\mathrm{ijk}} \mathrm{X}_{\mathrm{i}} \mathrm{X}_{\mathrm{j}} \mathrm{X}_{\mathrm{k}}
\end{aligned}
$$

Since SDA clay bricks have three components and the degree of the polynomial is two, then, the number of coefficients, $\mathrm{K}$, of the polynomial is as follows:

$$
\mathrm{K}=\frac{(3+2-1) !}{(3-1) !}=6
$$

For the SDA clay brick with three components, the response given by Eqn (5) becomes:

$$
\begin{aligned}
\mathrm{F}(\mathrm{x}) & =\mathrm{b}_{0}+\mathrm{b}_{1} \mathrm{X}_{1}+\mathrm{b}_{2} \mathrm{X}_{2}+\mathrm{b}_{3} \mathrm{X}_{3}+\mathrm{b}_{11} \mathrm{X}_{1}^{2}+b_{22} X_{2}^{2} \\
& +\mathrm{b}_{33} \mathrm{X}_{3}^{2}+b_{12} X_{1} X_{2}+b_{13} X_{1} X_{3}+b_{23} X_{2} X_{3}
\end{aligned}
$$

Eqn (7) is supposed to have six coefficients (i.e $\mathrm{K}=6$ ) as predicted from Eqn (6)

If Eqn (2) is multiplied by $X_{i}$, it becomes:

$\mathrm{X}_{\mathrm{i}} \mathrm{X}_{1}+\mathrm{X}_{\mathrm{i}} \mathrm{X}_{2}+\mathrm{X}_{\mathrm{i}} \mathrm{X}_{3}+\ldots+\mathrm{X}_{\mathrm{i}}^{2}+\ldots+\mathrm{X}_{\mathrm{i}} \mathrm{X}_{\mathrm{n}}=\mathrm{X}_{\mathrm{i}}$

Also, multiplying Eqn (3) by $\mathrm{b}_{0}$ gives the following product:

$$
\sum X_{i} b_{o}=\mathrm{b}_{0}
$$

From Eqn (8), Eqns (10) - (12) are obtained for a three component mixture

$$
\begin{aligned}
& X_{1}^{2}=X_{1}-X_{1} X_{2}-X_{1} X_{3} \\
& X_{2}^{2}=X_{2}-X_{1} X_{2}-X_{2} X_{3} \\
& X_{3}^{2}=X_{3}-X_{1} X_{3}-X_{2} X_{3}
\end{aligned}
$$

Expanding Eqn (9) yields Eqn (13),

$$
b_{0} X_{1}+b_{0} X_{2}+b_{0} X_{2}+b_{0} X_{3}=b_{0}
$$

Substituting Eqn (10) - (13) into Eqn (5) gives:

$\mathrm{F}(\mathrm{x})=\mathrm{b}_{0} \mathrm{X}_{1}+\mathrm{b}_{0} \mathrm{X}_{2}+\mathrm{b}_{0} \mathrm{X}_{3}+\mathrm{b}_{1} \mathrm{X}_{1}+\mathrm{b}_{2} \mathrm{X}_{2}+\mathrm{b}_{3} \mathrm{X}_{3}$

$$
\begin{aligned}
& +b_{11}\left(X_{1}-X_{1} X_{2}-X_{1} X_{3}\right)+b_{22}\left(X_{2}-X_{1} X_{2}-X_{2} X_{3}\right) \\
& +b_{33}\left(X_{3}-X_{1} X_{3}-X_{2} X_{3}\right)+b_{12} X_{1} X_{2} \\
& +b_{13} X_{1} X_{3}+b_{23} X_{2} X_{3}
\end{aligned}
$$

Rearranging Eqn (14) yields:

$\mathrm{F}(\mathrm{x})=\mathrm{X}_{1}\left(\mathrm{~b}_{0}+\mathrm{b}_{1}+\mathrm{b}_{11}\right)+\mathrm{X}_{2}\left(\mathrm{~b}_{0}+\mathrm{b}_{2}+\mathrm{b}_{22}\right)$

$$
\begin{aligned}
& +X_{3}\left(b_{0}+b_{3}+b_{33}\right)+X_{1} X_{2}\left(b_{12}-b_{11}-b_{22}\right) \\
& +X_{1} X_{3}\left(b_{13}-b_{11}-b_{33}\right)+X_{23}\left(b_{23}-b_{22}-b_{23}\right)
\end{aligned}
$$

Let the summation of the constants (given in brackets), be denoted as follows:

$$
\begin{aligned}
& \alpha_{1}=b_{0}+b_{1}+b_{11} \\
& \alpha_{2}=b_{0}+b_{2}+b_{22} \\
& \alpha_{3}=b_{0}+b_{3}+b_{33} \\
& \alpha_{12}=b_{12}-b_{11}-b_{22} \\
& \alpha_{13}=b_{13}-b_{11}-b_{33} \\
& \alpha_{23}=b_{23}-b_{22}-b_{33}
\end{aligned}
$$

Substituting Eqns (16) - (21) into Eqn (15), gives:

$$
F(x)=\alpha_{1} \mathrm{X}_{1}+\alpha_{2} \mathrm{X}_{2}+\alpha_{3} \mathrm{X}_{3}+\alpha_{12} \mathrm{X}_{1} \mathrm{X}_{2}+\alpha_{13} \mathrm{X}_{1} \mathrm{X}_{3}+\alpha_{23} \mathrm{X}_{2} \mathrm{X}_{3}
$$

Eqn (22) can be written in a compact form as follows:

$$
F(x)=\sum_{1 \leq j \leq \mathrm{q}}^{3} \alpha_{\mathrm{i}} \mathrm{X}_{\mathrm{i}}+\sum_{1 \leq \mathrm{i} \leq \mathrm{j}<\mathrm{q}} \alpha_{\mathrm{ij}} \mathrm{X}_{\mathrm{i}} \mathrm{X}_{\mathrm{j}}
$$

The Eqn (23) is the response to the pure component, ' $\mathrm{i}$ ' and the binary mixture "ij".

Thus, the response, $y_{i}$ for the pure component and the response, $y_{i}$ for the binary mixture components are respectively given as :

$$
y_{\mathrm{i}}=\sum \alpha_{\mathrm{i}} \mathrm{X}_{\mathrm{i}}
$$


and $y_{\mathrm{ij}}=\sum \alpha_{\mathrm{i}} \mathrm{X}_{\mathrm{i}}+\sum \alpha_{\mathrm{ij}} \mathrm{X}_{\mathrm{i}} \mathrm{X}_{\mathrm{j}}$

\subsubsection{COEFFICIENTS OF THE (3,2) SIMPLEX RESPONSE FUNCTION}

For a three component mixture in a two dimensional factor space, the vertices of a simplex lattice represents pure components while the mid points of the borderlines connecting the vertices represents the binary components.

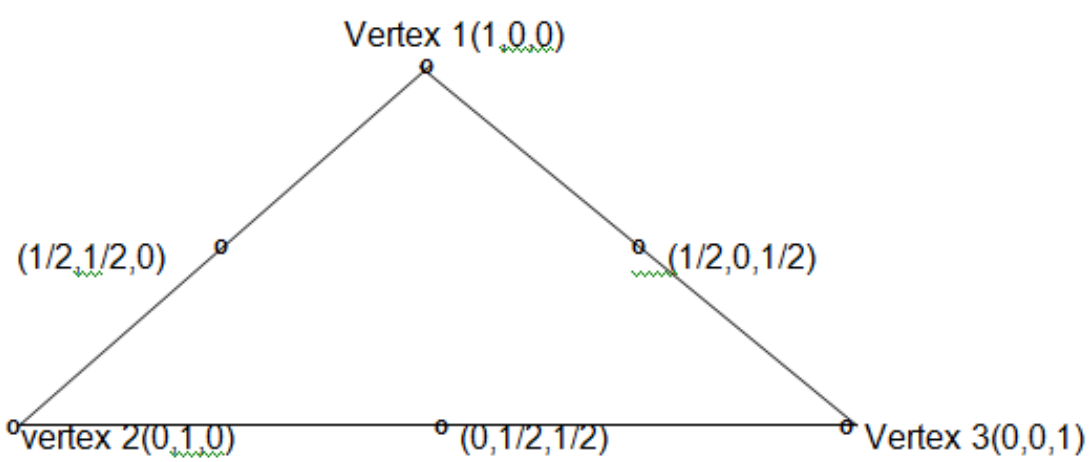

Fig 1: Simplex lattice for 2-dimensional factor space

At the first principal co-ordinate (i.e. at vertex 1), the quantity, $X_{1}=1$ while the other quantities $X_{2}$ and $X_{3}$ are all equal to zero. For the second vertex, the quantity, $X_{2}=1$ while all other quantities $X_{1}$ and $X_{3}$ are all equal to

zero. Let $n=\sum \alpha_{\mathrm{i}} \mathrm{X}_{\mathrm{i}}$

Substituting $X_{1}=1$ into Eqn (24) yields:

$\mathrm{n}_{1}=\propto_{1}$

Also, substituting $\mathrm{X}_{2}=1$ into Eqn (24) gives:

$n_{2}=\alpha_{2}$

Similarly

$\mathrm{n}_{3}=\alpha_{3}$

Generally, it can be represented thus:

$n_{i}=\alpha_{\mathrm{i}}$

and

$\mathrm{n}_{\mathrm{j}}=\alpha_{\mathrm{j}}$

For the midpoint of the borderline connecting the vertices 1 and 2 of the factor space,

$X_{1}=X_{2}=1 / 2$ while $X_{3}=0$.

Also, for the midpoint of the borderline connecting the vertices 1 and $3, X_{1}=X_{3}=1 / 2$ while $X_{2}=0$

And for the midpoint of the borderline connecting the vertices 2 and $3, X_{2}=X_{3}=1 / 2$ while $X_{1}=0$

Substituting into Eqn (25), the values of $X_{1}, X_{2}$ and $X_{3}$ at the midpoints of the borderline connecting the vertices 1 and 2, gives:

$n_{12}=\frac{1}{2} \alpha_{1}+\frac{1}{2} \alpha_{2}+\frac{1}{4} \alpha_{12}$

Similarly

$\mathrm{n}_{13}=\frac{1}{2} \alpha_{1}+\frac{1}{2} \alpha_{3}+\frac{1}{4} \alpha_{13}$

and

$\mathrm{n}_{23}=\frac{1}{2} \alpha_{2}+\frac{1}{2} \alpha_{3}+\frac{1}{4} \alpha_{23}$

Where $\mathrm{n}_{\mathrm{ij}}=\mathrm{y}_{\mathrm{ij}}$

Generally, Eqns (29) to (31) can be given as:

$\mathrm{n}_{\mathrm{ij}}=\frac{1}{2} \alpha_{i}+\frac{1}{2} \alpha_{j}+\frac{1}{4} \alpha_{i j}$ 
Rearranging Eqns (27), (28) and (32) gives respectively Eqn (33a), Eqn(33b) and Eqn(34)

$$
\begin{aligned}
& \alpha_{i}=\mathrm{n}_{\mathrm{i}} \\
& \alpha_{j}=\mathrm{n}_{\mathrm{j}}
\end{aligned}
$$

and

$\alpha_{i j}=4 \mathrm{n}_{\mathrm{ij}}-2 \alpha_{\mathrm{i}}-2 \alpha_{\mathrm{j}}$

substituting Eqns (33) into Eqn (34) yields:

$\alpha_{i j}=4 n_{\mathrm{ij}}-2 \mathrm{n}_{\mathrm{i}}-2 \mathrm{n}_{\mathrm{j}}$

Now, substituting Eqns (28) and (35) into Eqn (22) gives:

$\mathrm{F}(\mathrm{x})=\mathrm{n}_{1} \mathrm{X}_{1}+\mathrm{n}_{2} \mathrm{X}_{2}+\mathrm{n}_{3} \mathrm{X}_{3}+\mathrm{X}_{1} \mathrm{X}_{2}\left(4 \mathrm{n}_{12}-2 \mathrm{n}_{1}-2 \mathrm{n}_{2}\right)$

$$
+X_{1} X_{3}\left(4 n_{13}-2 n_{1}-2 n_{3}\right)+X_{2} X_{3}\left(4 n_{23}-2 n_{2}-2 n_{3}\right)
$$

Expanding Eqn (36) and collecting like terms together yields:

$\mathrm{F}(\mathrm{x})=\mathrm{n}_{1} \mathrm{X}_{1}\left(1-2 \mathrm{X}_{2}-2 \mathrm{X}_{3}\right)+\mathrm{n}_{2} \mathrm{X}_{2}\left(1-2 \mathrm{X}_{1}-2 \mathrm{X}_{3}\right)+\mathrm{n}_{3} \mathrm{X}_{3}\left(1-2 \mathrm{X}_{1}-2 \mathrm{X}_{2}\right)+4 \mathrm{n}_{12} \mathrm{X}_{1} \mathrm{X}_{2}$

$$
+4 \mathrm{n}_{13} \mathrm{X}_{1} \mathrm{X}_{3}+4 \mathrm{n}_{23} \mathrm{X}_{2} \mathrm{X}_{3} \text {. }
$$

Now multiplying Eqn (2) by 2 gives Eqn (38) for a three component mixture

$2 \mathrm{X}_{1}+2 \mathrm{X}_{2}+2 \mathrm{X}_{3}=2$.

Subtracting 1 from both sides of Eqn (38) yields:

Simplifying further gives:

$2 \mathrm{X}_{1}-1=1-2 \mathrm{X}_{2}-2 \mathrm{X}_{3}$

$2 \mathrm{X}_{2}-1=1-2 \mathrm{X}_{1}-2 \mathrm{X}_{3}$

$2 \mathrm{X}_{3}-1=1-2 \mathrm{X}_{1}-2 \mathrm{X}_{2}$

Substituting Eqns (40) - (42) into Eqn (37) yields Eqn (43):

$$
\begin{aligned}
\mathrm{F}(\mathrm{x}) & =\mathrm{n}_{1} \mathrm{X}_{1}\left(2 \mathrm{X}_{1}-1\right)+\mathrm{n}_{2} \mathrm{X}_{2}\left(2 \mathrm{X}_{2}-1\right)+\mathrm{n}_{3} \mathrm{X}_{3}\left(2 \mathrm{X}_{3}-1\right) \\
& +4 \mathrm{n}_{12} \mathrm{X}_{1} \mathrm{X}_{2}+4 \mathrm{n}_{13} \mathrm{X}_{1} \mathrm{X}_{3}+4 \mathrm{n}_{23} \mathrm{X}_{2} \mathrm{X}_{3}
\end{aligned}
$$

Eqn (43) is the simplex response function for determination of the crushing strength of SDA - clay bricks consisting of three components

\subsection{4:ACTUAL- PSEUDO MIX RATIOS OF COMPONENTS}

Mixture components are subject to the requirement that the sum of all the components, must be equal to unity (Scheffe, 1958). This implies that the sum of the mix ratios of the three actual components of SDA clay burnt brick (i.e. clay, sawdust and water) must be equal to one. Three different trial mix ratios are prescribed for these actual components located at the vertices $A_{1}, A_{2}$ and $A_{3}$ of the triangular simplex lattice. The trial mix ratios are as follows:

$\mathrm{A}_{1}(0.9,0.1,0.365), \mathrm{A}_{2}(0.8,0.2,0.35)$ and $\mathrm{A}_{3}(0.75,0.25$ and 0.345$)$.

Since the sum of the mix ratios of these actual components for each vertex is greater than one, the actual components, $\mathrm{Z}_{\mathrm{i}}$, must be transformed to pseudo components, $\mathrm{X}_{\mathrm{i}}$, using the following equation given by Scheffe's (1958)

$$
\mathrm{Z}=\mathrm{AX}
$$

From Eqn (44), Eqn (45) is obtained

$$
\mathrm{X}=\mathrm{BZ}
$$

Where Z- = matrix of actual components

$$
\begin{aligned}
\mathrm{A} & =\text { matrix of coefficients } \\
\mathrm{X} & =\text { matrix of pseudo components } \\
\mathrm{B} & =\text { inverse of matrix } \mathrm{A}
\end{aligned}
$$

The actual, Z-, and Pseudo, X- component mix ratios are determined and presented in Table 3.

Table 3: Laboratory crushing strength test Result

\begin{tabular}{|c|c|c|c|c|l|l|l|l|}
\hline $\begin{array}{c}\text { Points of } \\
\text { observation }\end{array}$ & $\begin{array}{c}\text { Mix } \\
\text { Nos }\end{array}$ & $\mathbf{S}_{\mathbf{1}}$ & $\mathbf{S}_{\mathbf{2}}$ & $\mathbf{S}_{\mathbf{3}}$ & $\begin{array}{l}\text { Response, } \\
\mathbf{Y}\end{array}$ & $\mathbf{Z}_{\mathbf{1}}$ & $\mathbf{Z}_{\mathbf{2}}$ & $\mathbf{Z}_{\mathbf{3}}$ \\
\hline $\mathrm{n}_{1}$ & Mix-1 & 9.5 & 3.2 .07 & 3.7 & $\mathrm{Y}_{1}$ & 6.934 & 3.65 & 2.700 \\
\hline $\mathrm{n}_{2}$ & Mix-2 & 8.0 & 3.0 & 3.55 & $\mathrm{Y}_{2}$ & 5.904 & 1.476 & 2.620 \\
\hline $\mathrm{n}_{3}$ & Mix-3 & 7.0 & 2.0 & 3.50 & $\mathrm{Y}_{3}$ & 5.185 & 2.222 & 2.593 \\
\hline $\mathrm{n}_{12}$ & Mix-4 & 8.75 & 1.25 & 3.625 & $\mathrm{Y}_{12}$ & 6.422 & 9.17 & 2.661 \\
\hline $\mathrm{n}_{13}$ & Mix-5 & 8.25 & 1.75 & 3.60 & $\mathrm{Y}_{13}$ & 6.066 & 1.287 & 2.647 \\
\hline
\end{tabular}




\begin{tabular}{|c|c|c|c|c|l|l|l|l|}
\hline $\mathrm{n}_{23}$ & Mix-6 & 7.5 & 2.5 & 3.525 & $\mathrm{Y}_{23}$ & 5.545 & 1.848 & 2.606 \\
\hline $\mathrm{c}_{1}$ & Mix-C 1 & 8.09 & 1.91 & 3.548 & $\mathrm{Y}_{\mathrm{c} 1}$ & 5.971 & 1.410 & 2.619 \\
\hline $\mathrm{c}_{2}$ & Mix- $\mathrm{C}_{2}$ & 0.84 & 1.6 & 3.6 & $\mathrm{Y}_{\mathrm{c} 2}$ & 6.177 & 1.177 & 2.647 \\
\hline $\mathrm{c}_{3}$ & Mix-C & 8.82 & 1.18 & 3.64 & $\mathrm{Y}_{\mathrm{c} 3}$ & 6.466 & 8.65 & 2.669 \\
\hline $\mathrm{c}_{4}$ & Mix-C & 8.925 & 1.07 & 3.648 & $\mathrm{Y}_{\mathrm{c} 4}$ & 6.542 & 7.84 & 2.674 \\
\hline $\mathrm{c}_{5}$ & Mix- $\mathrm{C}_{5}$ & 7.385 & 2.6128 & 3.527 & $\mathrm{Y}_{\mathrm{c} 5}$ & 5.460 & 1.932 & 2.608 \\
\hline $\mathrm{c}_{6}$ & mix-C $_{6}$ & 7.875 & 2.125 & 3.563 & $\mathrm{Y}_{\mathrm{c} 6}$ & 5.806 & 1.567 & 2.627 \\
\hline
\end{tabular}

\subsection{LABORATORY TESTS}

The test specimen used in this work, were cubic SDA - clay fired bricks each of dimension $76.2 \mathrm{~mm}$. They were prepared from the twelve mix ratios (given in Table 3), cured in water, dried and fired to a temperature of $600^{\circ} \mathrm{C}$ as recommended by Elinwa(2006), and thereafter crushed in a crushing machine. Out of the twelve mix ratios used in the test, the first set of six mix ratios, were used to produce SDA - clay bricks for determining the responses (crushing strength) required to obtain the final simplex response functions for predicting the crushing strength of SDA clay bricks. The other set of six mix ratios were used in verifying the adequacy of the simplex response function. For each mix ratio, three SDA - clay fired bricks were tested, and average crushing strength of the bricks determined and presented in Table 4.

\section{Results And Analysis}

The crushing strengths obtained from the laboratory tests are given in Table 4.

Table 4: Laboratory crushing strength test result

\begin{tabular}{|c|c|c|c|c|c|}
\hline \multirow{2}{*}{$\begin{array}{c}\text { Points of } \\
\text { observation }\end{array}$} & \multirow[t]{2}{*}{ Mix Nos } & \multicolumn{3}{|c|}{ Crushing Strengths $\left(\mathrm{KN} / \mathrm{mm}^{2}\right)$} & \multirow{2}{*}{$\begin{array}{l}\text { Average crushing } \\
\text { strength }\left(\mathrm{KN} / \mathrm{mm}^{2}\right)\end{array}$} \\
\hline & & Replicate 1 & Replicate 2 & Replicate 3 & \\
\hline $\mathrm{n}_{1}$ & Mix-1 & 28.10 & 28.37 & 28.48 & 28.32 \\
\hline $\mathrm{n}_{2}$ & Mix-2 & 18.32 & 17.84 & 17.93 & 18.03 \\
\hline $\mathrm{n}_{3}$ & Mix-3 & 14.37 & 14.46 & 14.32 & 14.35 \\
\hline $\mathrm{n}_{4}$ & Mix-4 & 24.43 & 24.77 & 24.81 & 24.67 \\
\hline $\mathrm{n}_{5}$ & Mix-5 & 20.61 & 20.53 & 20.88 & 20.67 \\
\hline $\mathrm{n}_{6}$ & Mix-6 & 17.59 & 17.68 & 17.58 & 17.62 \\
\hline $\mathrm{n}_{7}$ & ${\mathrm{Mix}-\mathrm{C}_{1}}_{1}$ & 19.20 & 19.05 & 18.77 & 19.01 \\
\hline $\mathrm{n}_{8}$ & Mix-C ${ }_{2}$ & 22.26 & 22.25 & 22.23 & 22.25 \\
\hline $\mathrm{n}_{9}$ & Mix- $\mathrm{C}_{3}$ & 25.39 & 25.03 & 24.84 & 25.08 \\
\hline $\mathrm{n}_{10}$ & Mix-C ${ }_{4}$ & 25.25 & 25.39 & 25.48 & 25.37 \\
\hline $\mathrm{N}_{11}$ & Mix- $\mathrm{C}_{5}$ & 16.13 & 16.15 & 15.99 & 16.09 \\
\hline $\mathrm{n}_{12}$ & $\operatorname{mix}-\mathrm{C}_{6}$ & 18.78 & 18.78 & 18.76 & 18.77 \\
\hline
\end{tabular}

The final simplex response function i.e. Eqn (46) for predicting crushing strength of SDA - clay fired bricks, is obtained by substituting the first six crushing strength test results (presented in Table 4) into Eqn (43)

$\mathrm{F}(\mathrm{x})=28.32 \mathrm{X}_{1}\left(2 \mathrm{X}_{1}-1\right)+18.03 \mathrm{X}_{2}\left(2 \mathrm{X}_{2}-1\right)+14.35 \mathrm{X}_{3}\left(2 \mathrm{X}_{3}-1\right)$

$$
+98.68 X_{1} X_{2}+90.28 X_{1} X_{3}+70.48 X_{2} X_{3}
$$

The final response function was tested and found adequate at $95 \%$ confidence level using T-statistic and Fstatistic tests. The results of these tests showed that the difference between the predicted and laboratory crushing strengths, are quite insignificant. The comparison of the predicted results in Tables 5, showed that the maximum percentage difference is $4.1 \%$, which is negligible.

Table 5: Comparison of Laboratory and predicted crushing strength of SDA - clay fired bricks

\begin{tabular}{|l|l|l|l|l|l|}
\hline $\begin{array}{l}\text { Points } \\
\text { observation }\end{array}$ & Mix Nos & $\begin{array}{l}\text { Laboratory } \\
\text { results } \\
\mathrm{KN} / \mathrm{mm}^{2}(\mathrm{~A})\end{array}$ & $\begin{array}{l}\text { Predicted } \\
\text { results } \\
\mathrm{KN} / \mathrm{mm}^{2}(\mathrm{~B})\end{array}$ & $\begin{array}{l}\text { Absolute } \\
\text { difference, (A- } \\
\text { B) }\end{array}$ & $\begin{array}{l}\text { Percentage } \\
\text { difference, (A- } \\
\text { B)/A }\end{array}$ \\
\hline $\mathrm{C}_{1}$ & Mix-C1 & 19.01 & 18.23 & 0.78 & $4.1 \%$ \\
\hline $\mathrm{C}_{2}$ & Mix-C2 & 22.25 & 22.42 & 0.17 & $0.8 \%$ \\
\hline $\mathrm{C}_{3}$ & Mix-C3 & 25.08 & 24.47 & 0.61 & $2.4 \%$ \\
\hline $\mathrm{C}_{4}$ & Mix-C4 & 25.37 & 25.19 & 0.18 & $0.71 \%$ \\
\hline $\mathrm{C}_{5}$ & Mix-C5 & 16.09 & 16.42 & 0.33 & $2.1 \%$ \\
\hline $\mathrm{C}_{6}$ & Mix-C6 & 18.88 & 19.22 & 0.45 & $2.4 \%$ \\
\hline
\end{tabular}




\section{Conclusions}

The following conclusions were drawn from the work

- The development of a response function for predicting the crushing strength of any new construction material, is a critical factor in the production and use of cheap and affordable construction materials.

- Simplex theory can be used successively to develop response function for predicting the crushing strength of building materials obtainable from a given mix proportion.The response functions can be used to predict accurately the crushing strength of SDA- clay burnt bricks when the mix proportions are known.

- Conversely, the response function can be used to predict the mix ratios of components that will yield a specified crushing strength.

\section{References}

[1]. Aggrawal, M.I. (2002); Mixture Experiments, Design workshop Lecture Notes, ISI, Ko Ikata pp 77-89Elinwa, A.U. (2006): Effect of addition of Sawdust ash to clay bricks. Civil Engineering and Environmental System, Vol. 13, NO.4, pp 263-270.

[2]. Elinwa, A.U. and Ejeh, S.P. (2004), Effects of incorporation of Sawdust waste and inciniretion fly ash in cements and mortar. IAABE, 3(1),pp1-7.

[3]. Elinwa, A.U. and Mamood, Y. A., (2002), Ash from Timber waste as a replacement material. Cements Concrete composites, 24,219-222.

[4]. Kasioti. M., Boura,P., Agatzini, S.,Tsakiridis, P. E and Oustadakis,P (2005). Use of Tarosite/Alunite Precipitrate as a substitute for Gypsum in Portland cement Cement and concrete composites. Journal, 2. pp3-9

[5]. Malu, S.P and Babson, A(2007), "Producing insulating refractory bricks with Kaolin and sawdust", J. for Engineering and Applied Science, 2(12), 197-199.

[6]. Nigerian Standard Organisation(1976) Specification for burnt clay building units, Nigerian Standard 74.

[7]. Okumade, E.A, (2008), "The Effect of wood ash and Sawdust ash Admixture on Engineering properties of Burnt Laterite-Clay Bricks", Journal of Applied Sciences, 8(6), 1042-1948.

[8]. Ramaswammy, S.D., Murthy, C.K. and Nagaraj, T.S. (1983), Use of waste material sand industrial by-products in concrete construction, Concrete Technology and Design vol1, New concrete materials edited by R.N. Swammy University press.

[9]. Scheffe, S.H.(1958). “Experiments with mixtures”' Royal Statistical Society, Series B, 25(2), 235-263. 